\title{
Triple oxygen isotopes indicate urbanization affects sources of nitrate in wet and dry atmospheric deposition
}

\author{
David M. Nelson ${ }^{1,2}$, Urumu Tsunogai ${ }^{2}$, Dong Ding ${ }^{2}$, Takuya Ohyama ${ }^{2}$, Daisuke D. Komatsu ${ }^{2, a}$, Fumiko Nakagawa ${ }^{2}$, \\ Izumi Noguchi ${ }^{3}$, and Takashi Yamaguchi ${ }^{3}$ \\ ${ }^{1}$ University of Maryland Center for Environmental Science, Appalachian Laboratory, Frostburg, MD 21532, USA \\ ${ }^{2}$ Nagoya University, Graduate School of Environmental Studies, Nagoya, 464-8601, Japan \\ ${ }^{3}$ Hokkaido Research Organization, Department of Environmental and Geological Research, \\ Institute of Environmental Sciences, Sapporo, 060-0819, Japan \\ ${ }^{a}$ present address: Tokai University, Department of Marine and Earth Science, Tokai, Japan
}

Correspondence: David M. Nelson (dnelson@umces.edu)

Received: 18 November 2017 - Discussion started: 2 January 2018

Revised: 29 March 2018 - Accepted: 18 April 2018 - Published: 4 May 2018

\begin{abstract}
Atmospheric nitrate deposition resulting from anthropogenic activities negatively affects human and environmental health. Identifying deposited nitrate that is produced locally vs. that originating from long-distance transport would help inform efforts to mitigate such impacts. However, distinguishing the relative transport distances of atmospheric nitrate in urban areas remains a major challenge since it may be produced locally and/or be transported from upwind regions. To address this uncertainty we assessed spatiotemporal variation in monthly weighted-average $\Delta^{17} \mathrm{O}$ and $\delta^{15} \mathrm{~N}$ values of wet and dry nitrate deposition during one year at urban and rural sites along the western coast of the northern Japanese island of Hokkaido, downwind of the East Asian continent. $\Delta^{17} \mathrm{O}$ values of nitrate in wet deposition at the urban site mirrored those of wet and dry deposition at the rural site, ranging between $\sim+23$ and $+31 \%$ o with higher values during winter and lower values in summer, which suggests the greater relative importance of oxidation of $\mathrm{NO}_{2}$ by $\mathrm{O}_{3}$ during winter and $\mathrm{OH}$ during summer. In contrast, $\Delta{ }^{17} \mathrm{O}$ values of nitrate in dry deposition at the urban site were lower $(+19-+25 \%)$ and displayed less distinct seasonal variation. Furthermore, the difference between $\delta^{15} \mathrm{~N}$ values of nitrate in wet and dry nitrate deposition was, on average, $3 \%$ greater at the urban than rural site, and $\Delta^{17} \mathrm{O}$ and $\delta^{15} \mathrm{~N}$ values were correlated for both forms of deposition at both sites with the exception of dry deposition at the urban site. These results suggest that, relative to nitrate in wet and dry deposition in rural environments and wet
\end{abstract}

deposition in urban environments, nitrate in dry deposition in urban environments forms from relatively greater oxidation of $\mathrm{NO}$ by peroxy radicals and/or oxidation of $\mathrm{NO}_{2}$ by $\mathrm{OH}$. Given greater concentrations of peroxy radicals and $\mathrm{OH}$ in cities, these results imply that dry nitrate deposition results from local $\mathrm{NO}_{x}$ emissions more so than wet deposition, which is transported longer distances. These results illustrate the value of stable isotope data for distinguishing the transport distances and reaction pathways of atmospheric nitrate pollution.

\section{Introduction}

The world's urban population has rapidly grown in recent decades, and this trend is expected to continue for at least a generation (United Nations, 2014). Besides socioeconomic transformation, urbanization also has environmental consequences, such as air pollution (Bloom et al., 2008; Cumming et al., 2014; Akimoto, 2003; Gurjar et al., 2016; von Glasow et al., 2013). For example, fossil fuel combustion from mobile and stationary sources produces nitrogen oxides $\left(\mathrm{NO}_{x}=\mathrm{NO}+\mathrm{NO}_{2}\right)$, which mediate atmospheric ozone $\left(\mathrm{O}_{3}\right)$ and fine-particle production, thus affecting human health. Furthermore, oxidation of $\mathrm{NO}_{x}$ leads to the formation of nitrate $\left(\mathrm{NO}_{3}^{-}\right)$, which when deposited on the Earth's surface contributes to the acidification and eutrophication of ecosystems (Galloway et al., 2004; Brown et al., 2006; Crutzen, 

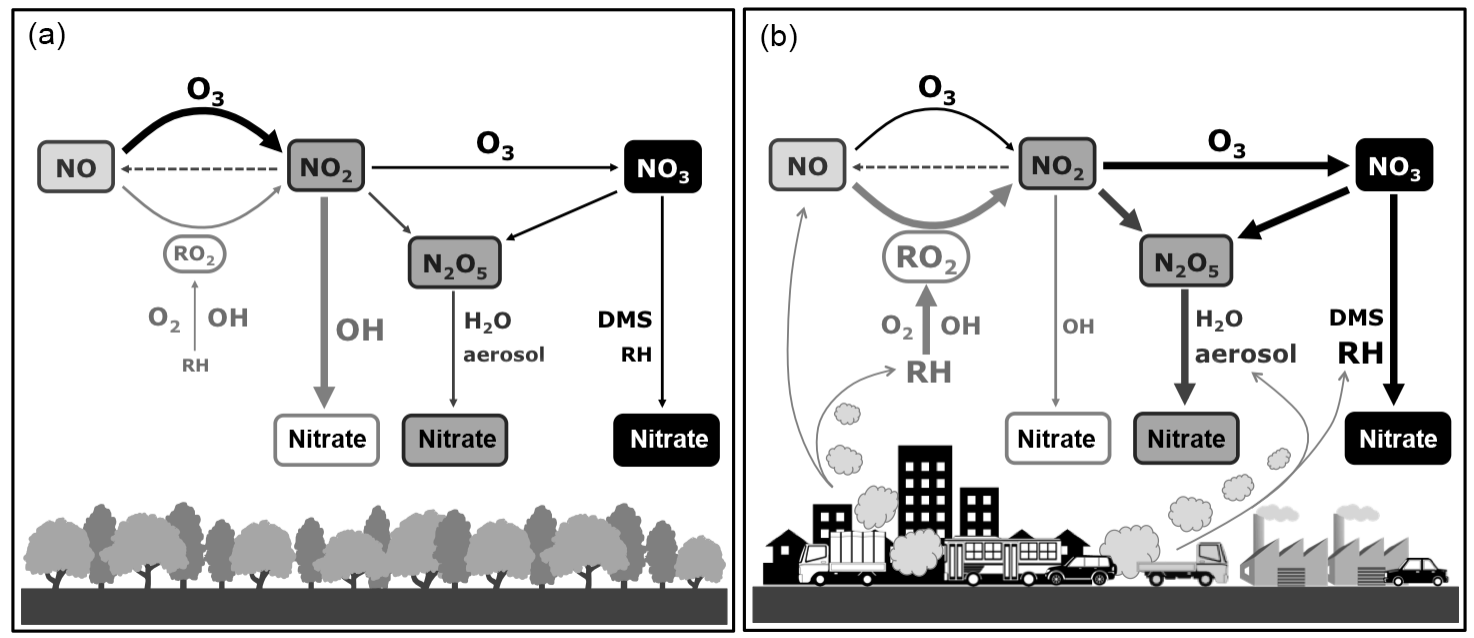

Figure 1. Conceptual diagrams of pathways for conversion of $\mathrm{NO}_{x}\left(\mathrm{NO}+\mathrm{NO}_{2}\right)$ to nitrate $\left(\mathrm{NO}_{3}^{-}\right)$in $($a) background atmosphere and (b) urban atmosphere. The first step in the process is the conversion of $\mathrm{NO}$ to $\mathrm{NO}_{2}$, which is accomplished primarily by $\mathrm{O}_{3}$ or peroxy radicals $\left(\mathrm{HO}_{2}+\mathrm{RO}_{2}\right)$. The second step is the oxidation of $\mathrm{NO}_{2}$. In daylight $\mathrm{OH}$ oxidizes $\mathrm{NO}_{2}$ to nitrate and at night $\mathrm{O}_{3}$ oxidizes $\mathrm{NO}_{2}$ to nitrate. Reactions with dimethylsulfide (DMS) or reactive hydrocarbons ( $\mathrm{RH}$ ) or $\mathrm{NO}_{2}$ (to form $\mathrm{N}_{2} \mathrm{O}_{5}$, followed by hydrolysis on aerosol surfaces) provide a pathway for nitrate deposition. Thicker arrows and larger fonts suggest greater relative importance of different pathways between panels on an annual basis. These diagrams are oversimplifications and the arrow and font sizes are qualitative. Furthermore, these diagrams ignore potential seasonal variation, such as the $\mathrm{N}_{2} \mathrm{O}_{5}$ pathway being relatively more important in rural environments during winter than summer and the $\mathrm{OH}$ pathway being relatively more important in urban environments during summer than winter.

1979). Efforts to reduce $\mathrm{NO}_{x}$ emissions can mitigate nitrate deposition (Liu et al., 2016; Zhao et al., 2015), but $\mathrm{NO}_{x}$ and atmospheric nitrate are also transported long distances and thus can affect areas far downwind of production hotspots (Holtgrieve et al., 2011; Akimoto, 2003; Lin et al., 2017). The pathways that transform $\mathrm{NO}_{x}$ to nitrate (Fig. 1), as well as the spatiotemporal patterns of atmospheric nitrate deposition, are relatively well understood (Ban et al., 2016; Li et al., 2016). However, it remains challenging to identify the sources of many pollutants, including nitrate produced locally vs. that originating from long-distance transport, which impedes efforts to improve air quality and environmental conditions (Wagstrom and Pandis, 2011; Skyllakou et al., 2014).

The stable nitrogen and oxygen isotope compositions of nitrate have been suggested as potential tracers of the sources and fate of $\mathrm{NO}_{x}$ in the environment (Elliott et al., 2009; Kendall et al., 2007; Freyer et al., 1993). Nitrogen isotopes $\left(\delta^{15} \mathrm{~N}\right)$ of nitrate can potentially reflect those of $\mathrm{NO}_{x}$, but mass-dependent isotopic fractionations during the oxidation of $\mathrm{NO}_{x}$ to nitrate can also alter the original $\delta^{15} \mathrm{~N}$ value of $\mathrm{NO}_{x}$, thus complicating efforts to use $\delta^{15} \mathrm{~N}$ values of nitrate for source partitioning (e.g., Walters and Michalski, 2015, 2016; Walters et al., 2016). A unique alternative that has recently emerged is the triple oxygen isotope $\left(\Delta^{17} \mathrm{O}\right)$ value of nitrate ${ }^{1}$, which reflects (as the result of mass-independent

${ }^{1} \Delta{ }^{17} \mathrm{O}$
$\Delta^{17} \mathrm{O}_{\text {nitrate }}=\frac{{ }_{\text {values }}+\delta^{17} \mathrm{O}_{\text {nitrate }}}{\left(1+\delta^{18} \mathrm{O}_{\text {nitrate }}\right)^{\beta}}-1, \quad \begin{gathered}\text { defined } \\ \text { where }\end{gathered}$

isotopic fractionation during the formation of $\mathrm{O}_{3}$ ) the number of oxygen atoms derived from $\mathrm{O}_{3}$ that are involved in the oxidation of $\mathrm{NO}_{x}$ (Alexander et al., 2009; Morin et al., 2008; Michalski et al., 2003; Tsunogai et al., 2010, 2016) since direct emissions of nitrate during combustion are relatively small (Fraser et al., 1998). An advantage of $\Delta^{17} \mathrm{O}$ relative to $\delta^{18} \mathrm{O}$ of nitrate is that $\Delta^{17} \mathrm{O}$ values are primarily a function of the chemical pathways of nitrate formation, whereas $\delta^{18} \mathrm{O}$ values are also influenced by $\delta^{18} \mathrm{O}$ of atmospheric water and temperature (Michalski et al., 2011). The fraction of $\mathrm{NO}$ oxidized to $\mathrm{NO}_{2}$ by $\mathrm{O}_{3}$ relative to peroxy radicals $\left(\mathrm{HO}_{2}+\mathrm{RO}_{2}\right)$ determines two-thirds of the $\Delta^{17} \mathrm{O}$ value of nitrate. The remaining fraction results from the extent to which $\mathrm{O}_{3} \mathrm{vs}$. $\mathrm{OH}$ molecules oxidize $\mathrm{NO}_{2}$ (Geng et al., 2017). $\Delta^{17} \mathrm{O}$ values of atmospheric nitrate deposition are often highest in winter and lowest in summer (Michalski et al., 2003; Savarino et al., 2007; Tsunogai et al., 2010, 2016), because longer periods of darkness and lower temperatures favor the oxidation of $\mathrm{NO}_{x}$ by $\mathrm{O}_{3}$, as well as $\mathrm{N}_{2} \mathrm{O}_{5}$ hydrolysis reactions, whereas oxidation of $\mathrm{NO}_{2}$ by $\mathrm{OH}$ is more important when daylight is longer and temperatures higher (Fig. 1). Peroxy radicals, which form from the oxidation of carbon monoxide, reactive hydrocarbons, and volatile organic compounds (Saito et al., 2002), are thought to compete with $\mathrm{O}_{3}$ to oxidize $\mathrm{NO}$ in polluted settings and thus depress $\Delta^{17} \mathrm{O}$ values of nitrate (Guha

$\delta=\left[R_{\text {sample }} / R_{\text {standard }}\right]-1$, and $R$ represents the elemental ratios (i.e., ${ }^{17} \mathrm{O} /{ }^{16} \mathrm{O}$ and ${ }^{18} \mathrm{O} /{ }^{16} \mathrm{O}$ ) between a sample and standard. 


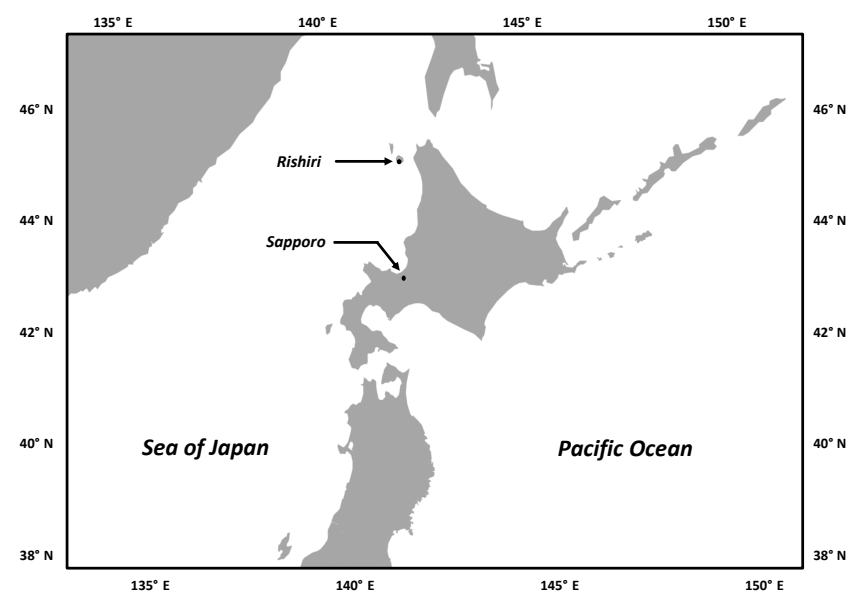

Figure 2. Location of study sites, Rishiri and Sapporo, in northern Japan. The base layer of the map was obtained from https://www. amcharts.com/svg-maps/.

et al., 2017; Fang et al., 2011). Decreasing nitrate- $\Delta^{17} \mathrm{O}$ values during the past $\sim 150$ years in West Antarctica suggest that anthropogenic activities have increased the relative importance of peroxy radicals in $\mathrm{NO}_{x}$ cycling globally (Sofen et al., 2014). However, reactive hydrocarbons and aerosols can also facilitate the formation of nitrate directly or through $\mathrm{N}_{2} \mathrm{O}_{5}$, respectively, which elevates $\Delta^{17} \mathrm{O}$ values of nitrate (Michalski et al., 2011). Although wet (aqueous nitrate) and dry (gaseous $\mathrm{HNO}_{3}$ or particulate nitrate) deposited nitrate are often presumed to have similar $\Delta^{17} \mathrm{O}$ values (Guerrieri et al., 2015), dry deposition may be less prone to long-distance transport (Celle-Jeanton et al., 2009; Dasch and Cadle, 1985; Balestrini et al., 2000). Shorter transport distances could lead to distinct oxidation pathways and thus different $\Delta^{17} \mathrm{O}$ values of nitrate between these forms of deposition in urban environments where concentrations of atmospheric pollutants are typically elevated. Yet, this hypothesis cannot be evaluated using existing data, as prior studies typically analyzed $\Delta{ }^{17} \mathrm{O}$ values of only wet or dry nitrate deposition at single sites (Guha et al., 2017; Tsunogai et al., 2010).

In this paper we assess the effect of urbanization on the oxidation chemistry of $\mathrm{NO}_{x}$ and the sources of nitrate in wet and dry atmospheric deposition using measurements of the $\Delta^{17} \mathrm{O}, \delta^{18} \mathrm{O}$, and $\delta^{15} \mathrm{~N}$ values of nitrate. Our two study sites (Fig. 2) are located at a similar longitude, are separated by only $\sim 2^{\circ}$ of latitude, and have comparable synoptic climatologies, but there is a major difference in the degree of urbanization between them (see below). These sites were chosen to be downwind of several megacities on the East Asian continent, a region where $\mathrm{NO}_{x}$ emissions have increased approximately four-fold during the past 40 years (Akimoto, 2003; Uno et al., 2007). This arrangement of sites provides an ideal setting to investigate potential differences in the oxidation pathways and sources of nitrate pollution in urban and rural environments against high background levels of atmospheric nitrate deposition.

\section{Material and methods}

\subsection{Study sites}

Rishiri is a remote (population size: $\sim 5000$; density: $\sim 28$ people $\mathrm{km}^{-2}$ ) and small island in the Sea of Japan off the coast of the island of Hokkaido in northern Japan. Samples of wet and dry atmospheric deposition were collected at the Rishiri National Acid Rain Monitoring station (Fig. 2; $45^{\circ} 07^{\prime} 11^{\prime \prime} \mathrm{N}, 141^{\circ} 12^{\prime} 33^{\prime \prime} \mathrm{E}$; $40 \mathrm{~m}$ a.s.l.), which is part of the Acid Deposition Monitoring Network in East Asia (EANET), between January and December in 2009. The mean annual precipitation is $\sim 920 \mathrm{~mm}$ and mean annual temperature is $\sim 7.1^{\circ} \mathrm{C}$ (http://www.jma.go.jp/jma/indexe. html). Precipitation is highest in the late summer through winter, and lower in spring and early summer. The main land cover within $\mathrm{a} \sim 10 \mathrm{~km}$ radius of the monitoring station is forest and shrub land.

Sapporo is a city of $\sim 1.9$ million people (density: $\sim 1710$ people $\mathrm{km}^{-2}$ ) which is $\sim 200 \mathrm{~km}$ south of Rishiri. Samples of wet and dry atmospheric deposition were obtained from the roof of the Institute of Environmental Sciences in Sapporo (Fig. 2; $43^{\circ} 04^{\prime} 55^{\prime \prime} \mathrm{N}, 141^{\circ} 20^{\prime} 00^{\prime \prime} \mathrm{E}$; $\sim 26 \mathrm{~m}$ a.s.1.) between January and December in 2009. The sampling site in Sapporo is not part of EANET. The mean annual precipitation is $\sim 1100 \mathrm{~mm}$ and mean annual temperature is $\sim 8.9^{\circ} \mathrm{C}$ (http://www.jma.go.jp/jma/indexe.html). Rishiri and Sapporo are both located on the Sea of Japan side of Hokkaido prefecture and thus have similar seasonal precipitation patterns and air-mass back-trajectories on daily and longer timescales. Sapporo is bordered by the Sea of Japan to the north and by mountains to the west, south, and east. The major sources of local $\mathrm{NO}_{x}$ emissions are automobile exhaust and boilers used for domestic heating. There are no major factories or combustion-based electricity generation facilities in Sapporo. The prevailing winds in Hokkaido typically originate from the northwest in winter and southeast in summer (Kaneyasu et al., 1995).

\subsection{Sample collection}

Samples were collected using the standard operating methods of EANET (http://www.eanet.asia/product/manual/ techacm.pdf). Composite samples of wet deposition falling on a daily and weekly basis were collected at Rishiri $(n=$ $62)$ and Sapporo $(n=41)$, respectively, using auto samplers (DKK DRS-200(S), DKK and US-420, Ogasawara Keiki Corp, respectively). The wet deposition samples were filtered through a $0.45 \mu \mathrm{m}$ filter and stored at $4{ }^{\circ} \mathrm{C}$ until measurements of nitrate and nitrite $\left(\mathrm{NO}_{2}^{-}\right)$concentrations and isotopes were carried out. 
Samples of dry deposition were obtained using the filterpack method, which has been widely used in dry deposition monitoring programs throughout the world (Aikawa et al., 2010; Endo et al., 2011; Mehlmann and Warneck, 1995; Tørseth et al., 1999). At each site, air was drawn through a six-stage filter pack at a rate of $4 \mathrm{~L} \mathrm{~min}^{-1}$ to collect gaseous $\mathrm{HNO}_{3}$ and particulate nitrate. Composite samples collected using this approach (which we refer to as dry deposition) were obtained on a monthly basis at Rishiri $(n=12)$. Sampling of dry deposition at Sapporo occurred approximately bi-weekly $(n=24)$; sampling occurred bi-weekly rather than monthly (as at Rishiri) because we anticipated higher nitrate concentrations in dry deposition at Sapporo than Rishiri. However, only 15 of the 24 dry deposition samples from Sapporo were available for analysis in the present study. The first stage of the filter pack is a multi-nozzle cascade impactor (NL-4-10P, Tokyo Dylec. Corp.) and Teflon binder filter (T60A20-20H, Tokyo Dylec. Corp.) that collects coarse particles $>10 \mu \mathrm{m}$ in diameter. The second stage is a Teflon filter (ADVANTEC T080A047A) that collects fine particles $<10 \mu \mathrm{m}$ in diameter that passed through the first filter. The third stage is a $0.45 \mu \mathrm{m}$ nylon filter (PALL ULTIPOR N66-NX047100) that collects $\mathrm{HNO}_{3}$ gas and some $\mathrm{SO}_{2}$, $\mathrm{HCl}, \mathrm{HONO}, \mathrm{NH}_{3}$, and $\mathrm{NO}_{2}$. The fourth and fifth stage filters (ADVANTEC No. 51A, alkaline impregnated filter) are used to collect the remaining $\mathrm{SO}_{2}, \mathrm{HCl}$, and $\mathrm{HONO}$. The last filter (ADVANTEC No. 51A, acid impregnated filter) is used to collect the remaining $\mathrm{NH}_{3}$. The nitrate and nitrite on the first, second, and third filters were extracted using ultrapure water, passed through a $0.45 \mu \mathrm{m}$ filter, and stored at $4{ }^{\circ} \mathrm{C}$ until measurement of nitrate and nitrite concentrations and isotopes was carried out.

The maximum filter blank was $0.2 \mu \mathrm{g}(=3 \mathrm{nmol})$ for nitrate, which corresponds to $0.16 \mu \mathrm{mol} \mathrm{L}^{-1}$ nitrate when $20 \mathrm{~mL}$ of Milli-Q water is used to extract nitrate from each filter based on the EANET procedure. The minimum nitrate concentrations in the solutions extracted from the filters and measured for isotopic values were 30.7, 1.5, and $22.4 \mu \mathrm{mol} \mathrm{L}^{-1}$ in the portions of coarse particles, fine particles, and gas, respectively, for Rishiri, and 26.1, 3.5, and $10.2 \mu \mathrm{mol} \mathrm{L}^{-1}$ in the portions of coarse particles, fine particles, and gas, respectively, for Sapporo. Thus, we concluded that the blanks had little influence on the isotopic values of dry deposition. This is true even for fine particle samples with nitrate concentrations $<5 \mu \mathrm{mol} \mathrm{L}{ }^{-1}$, because the deposition rates of these nitrate-depleted samples were low. We did not directly assess filter breakthrough limits, but prior results based on changes in the duration of sampling at our sites suggest that such limits are much higher than the amount of nitrate present in our samples (Noguchi et al., 2009).

\subsection{Analysis}

Within a few months of collection, nitrate and nitrite in the filtered samples of wet and dry deposition were quantified using ion chromatography (Dionex DX-500, ICS-1500 and ICS-2000, Nippon Dionex Co., Ltd., Osaka, Japan). Based on replicate analyses of samples, the precision of these concentration measurements was $1.6 \%$; the detection limit was $0.03 \mu \mathrm{mol} \mathrm{L}^{-1}$. Nitrite concentrations were $<1.0 \%$ of the sum of nitrite and nitrate concentrations in all samples of wet deposition, and they were $\leq 5.0 \%$ in 72 and $87 \%$ of samples of dry deposition at Rishiri and Sapporo, respectively. The $\mathrm{pH}$ values of the wet deposition samples ranged between 4.51 and 5.02 at Rishiri and between 4.65 and 5.29 at Sapporo.

Isotopic analysis was performed in 2013 for samples from Rishiri and in 2011 for samples from Sapporo. Prior to isotopic analysis we reanalyzed nitrate and nitrate concentrations in the samples and found that differences between these and the original concentration measurements were $<10 \%$. For isotopic analysis, nitrite and nitrate in each filtrate sample was converted to $\mathrm{N}_{2} \mathrm{O}$ using chemical conversion (McIlvin and Altabet, 2005) with slight modification (Tsunogai et al., 2008, 2016). Isotopic analysis of nitrite alone was also performed on samples with nitrite concentrations $>5.0 \%$ of the total nitrite plus nitrate concentrations (Mcllvin and Altabet, 2005). The $\delta^{15} \mathrm{~N}, \delta^{18} \mathrm{O}$, and $\Delta^{17} \mathrm{O}$ values of $\mathrm{N}_{2} \mathrm{O}$ in each vial were determined using a continuous-flow isotope ratio mass spectrometry system (Komatsu et al., 2008; Hirota et al., 2010). The obtained $\delta^{18} \mathrm{O}$ values were normalized to VSMOW using local laboratory nitrate standards calibrated against USGS34 $\left(\delta^{18} \mathrm{O}=-27.9 \%\right.$ o, $\Delta^{17} \mathrm{O}=0.04 \%$ o, and $\delta^{15} \mathrm{~N}=-1.8 \%$ o $)$ and USGS35 $\left(\delta^{18} \mathrm{O}=+57.5 \%, \quad \Delta^{17} \mathrm{O}=+20.88 \%\right.$, and $\delta^{15} \mathrm{~N}=+2.7 \%$ ) (Kaiser et al., 2007). $\Delta^{17} \mathrm{O}$ values were measured directly from the $\delta^{33}$ and $\delta^{34}$ of $\mathrm{O}_{2}$ data. The obtained $\delta^{15} \mathrm{~N}$ values were normalized to AIR using local laboratory nitrate standards calibrated against USGS32 $\left(\delta^{18} \mathrm{O}=+25.7 \%\right.$ and $\delta^{15} \mathrm{~N}=+180 \%$ ) and USGS34. The $\delta^{18} \mathrm{O}$ and $\delta^{15} \mathrm{~N}$ values of the three local standards range between 1.1 and $22.4 \%$ and between -2.1 and $11.8 \%$, respectively. The $\Delta^{17} \mathrm{O}$ values of the local standards are $\sim 0 \%$. Analytical precision $(1 \sigma)$ was $\pm 0.3 \%$ o for $\delta^{15} \mathrm{~N}, \pm 0.5 \%$ ofor $\delta^{18} \mathrm{O}$, and $\pm 0.2 \%$ for $\Delta^{17} \mathrm{O}$ based on repeated measurements of the local nitrate standards (Tsunogai et al., 2010). Besides using the local nitrate standards for routine calibration and as checks of isotopic fractionation and oxygen isotope exchanges, we also analyzed USGS34 and USGS35 at least monthly to assess instrument linearity.

For samples with nitrite concentrations $>5 \%$ of the total nitrite plus nitrate concentrations the $\delta^{15} \mathrm{~N}$ and $\delta^{18} \mathrm{O}$ values of nitrate were calculated by mass balance (e.g., $\delta^{15} \mathrm{~N}_{\mathrm{NO}_{3}}^{-}=\left(\delta^{15} \mathrm{~N}_{\mathrm{NO}_{2}{ }^{-}+\mathrm{NO}_{3}{ }^{-}}{ }^{*}\left[\mathrm{NO}_{2}^{-}+\mathrm{NO}_{3}^{-}\right]-\delta^{15} \mathrm{~N}_{\mathrm{NO}_{2}}^{-}{ }^{*}\right.$ $\left.\left.\left[\mathrm{NO}_{2}^{-}\right]\right) /\left[\mathrm{NO}_{3}^{-}\right]\right)$. The measured $\Delta^{17} \mathrm{O}$ value of nitrite for samples on which this analysis was performed was $0 \%$. Therefore, we presumed that the $\Delta^{17} \mathrm{O}$ value of nitrite is $0 \%$ because of rapid oxygen exchange between $\mathrm{NO}_{2}$ and water at near-neutral $\mathrm{pH}$ condition (Casciotti et al., 2007), and we corrected the $\Delta^{17} \mathrm{O}$ values of nitrate 
as $\Delta^{17} \mathrm{O}_{\mathrm{NO}_{3}}^{-}=\Delta^{17} \mathrm{O}_{\mathrm{NO}_{2}^{-}+\mathrm{NO}_{3}^{-}}{ }^{*}\left[\mathrm{NO}_{2}^{-}+\mathrm{NO}_{3}^{-}\right] /\left[\mathrm{NO}_{3}^{-}\right]$. For all samples (at both sites), the maximum nitrite/nitrate ratios in the samples were 28.6, 13.3, and $7.4 \%$ for coarse particles, fine particles, and gas, respectively. Therefore, the maximum extent of $\delta^{15} \mathrm{~N}$ corrections for the limited number of dry deposition samples with nitrite concentrations $>5 \%$ of the total nitrite plus nitrate concentrations were $1.1,0.9$, and $<0.1 \%$, respectively, the maximum extent of $\delta^{18} \mathrm{O}$ corrections were $15.0,11.2$, and $<0.1 \%$, respectively, and the maximum extent of $\Delta^{17} \mathrm{O}$ corrections were 5.7, 3.1, and $0.4 \%$, respectively. From these results we conclude that the potential bias in the isotopic values of dry deposition associated with nitrite was much smaller than the errors assumed in the final total isotopic values of dry deposition (around $\pm 2.5 \%$ o for $\delta^{15} \mathrm{~N}, \pm 8.0 \%$ ofor $\delta^{18} \mathrm{O}$, and $\pm 3 \%$ o for $\Delta^{17} \mathrm{O}$ ).

To quantify the $\Delta^{17} \mathrm{O}, \delta^{18} \mathrm{O}$, and $\delta^{15} \mathrm{~N}$ values of nitrate in dry deposition, we calculated monthly weighted-average (weighted based on mass) $\Delta^{17} \mathrm{O}, \delta^{18} \mathrm{O}$, and $\delta^{15} \mathrm{~N}$ values of nitrate (e.g., $\Delta^{17} \mathrm{O}_{\text {dry }}, \delta^{18} \mathrm{O}_{\text {dry }}$ and $\delta^{15} \mathrm{~N}_{\text {dry }}$, respectively) among coarse and fine particles and gas phases using each isotopic value and concentration. For Sapporo, isotopic values for samples of dry deposition collected during the same month were averaged as monthly weighted-average values. To compare isotopic values of wet and dry deposition within and between sites, we calculated monthly weighted-average $\Delta^{17} \mathrm{O}, \delta^{18} \mathrm{O}$ and $\delta^{15} \mathrm{~N}$ values of nitrate for wet deposition (e.g., $\Delta{ }^{17} \mathrm{O}_{\text {wet }}, \delta^{18} \mathrm{O}_{\text {wet }}$ and $\delta^{15} \mathrm{~N}_{\text {wet }}$ ). Paired $t$ tests were used to compare monthly weighted-average $\Delta^{17} \mathrm{O}_{\text {wet }}$ and $\Delta^{17} \mathrm{O}_{\text {dry }}, \delta^{18} \mathrm{O}_{\text {wet }}$ and $\delta^{18} \mathrm{O}_{\text {dry }}$, and $\delta^{15} \mathrm{~N}_{\text {wet }}$ and $\delta^{15} \mathrm{~N}_{\text {dry }}$, within sites. Paired $t$ tests were also used to compare monthly weighted-average $\Delta^{17} \mathrm{O}_{\text {coarse }}$ and $\Delta^{17} \mathrm{O}_{\text {fine }}, \delta^{18} \mathrm{O}_{\text {coarse }}$ and $\delta^{18} \mathrm{O}_{\text {fine }}$, and $\delta^{15} \mathrm{~N}_{\text {coarse }}$ and $\delta^{15} \mathrm{~N}_{\text {fine }}$ at each site. A one-way ANOVA was used to compare monthly weighted-average $\Delta{ }^{17} \mathrm{O}_{\text {wet }}$ and $\Delta{ }^{17} \mathrm{O}_{\text {dry }}$ at Rishiri with $\Delta{ }^{17} \mathrm{O}_{\text {wet }}$ at Sapporo, as well as $\delta^{15} \mathrm{~N}_{\text {wet }}$ and $\delta^{15} \mathrm{~N}_{\text {dry }}$ at Rishiri with $\delta^{15} \mathrm{~N}_{\text {wet }}$ at Sapporo. Statistical analyses were performed in PAST version 3.01 (Hammer et al., 2001). Volatilization of particulate to gaseous nitrate that occurs using the filter-pack method (e.g., Noguchi et al., 2009) may bias assessment of the isotopic values of gaseous and particulate nitrate. Therefore, we do not compare the concentrations and isotopic values of particulate and gaseous nitrate at our sites.

Wet deposition flux was calculated using precipitation amount and nitrate concentration data obtained for each site from the National Institute for Environmental Studies, Japan (http://www.nies.go.jp/index-e.html). The monthly flux is the sum of precipitation amount multiplied by the nitrate concentration for all samples in each month. Dry deposition flux was estimated following the inferential method (Hicks, 1986), where

$F_{\text {dry }}=V_{\mathrm{d}} \times C$

and $F_{\text {dry }}$ represents the dry deposition flux, $V_{\mathrm{d}}$ the deposition velocity, and $C$ the nitrate concentration in air (calculated from measured nitrate concentrations in the sample extracts and pumped air volume). Calculation of $V_{\mathrm{d}}$ by the inferential method requires meteorological and land use data. Meteorological data were obtained from the Japan Meteorological Agency (http://www.jma.go.jp/jma/indexe.html). Land use was presumed to be forest at Rishiri and city at Sapporo. The height of the forest canopy at Rishiri was presumed to be $10 \mathrm{~m}$, and seasonal canopy resistance was determined from NDVI values (Noguchi et al., 2006). Deposition velocity was calculated using the inferential method version 4.2 (Noguchi et al., 2011; Wesely, 1989; Walcek et al., 1986; Erisman et al., 1997; Zhang et al., 2003) (the program file is available at http://www.hro.or.jp/list/environmental/research/ies/ katsudo/acid_rain/kanseichinchaku/dry_deposition.html).

Deposition velocities of gaseous and particulate materials are estimated separately, although these results should be interpreted with caution because of the potential for bias from volatilization of particulate nitrate. Fluxes of coarse and fine particles were not differentiated.

\section{Results}

At the rural site, Rishiri, there was no difference between monthly weighted-average $\Delta^{17} \mathrm{O}_{\text {dry }}$ and $\Delta \Delta^{17} \mathrm{O}_{\text {wet }}$, which ranged between +22.3 and $+30.1 \%$ and between +22.7 and $+30.3 \%$, respectively (Fig. $3 ; p=0.57, n=12$ ). Monthly weighted-average $\delta^{18} \mathrm{O}_{\text {dry }}$ was slightly less overall than $\delta^{18} \mathrm{O}_{\text {wet }}$, with ranges between +66.9 and $+94.4 \%$ o and +71.2 and $+90.9 \%$ o, respectively (Fig. $3 ; p=0.005$, $n=12$ ). Both forms of deposition generally exhibited larger $\Delta^{17} \mathrm{O}$ and $\delta^{18} \mathrm{O}$ values in winter than in summer (Figs. 3 and 4 ). $\Delta^{17} \mathrm{O}_{\text {coarse }}$ was more positive (by $4.2 \%$, on average) than $\Delta^{17} \mathrm{O}_{\text {fine }}(p=0.002, n=10)$ and $\delta^{18} \mathrm{O}_{\text {coarse }}$ was more positive (by $4.6 \%$, on average) than $\delta^{18} \mathrm{O}_{\text {fine }}$ ( $p=0.01, n=12$; Fig. S1 in the Supplement). Monthly weighted-average $\delta^{15} \mathrm{~N}_{\text {dry }}$ at Rishiri varied between -4.8 and $+7.5 \%$ and was on average $3.5 \%$ larger than $\delta^{15} \mathrm{~N}_{\text {wet }}$, which varied between -8.6 and $+2.0 \%$ (Fig. $3 ; p=0.02$, $n=12) . \delta^{15} \mathrm{~N}_{\text {coarse }}$ was slightly lower than $\delta^{15} \mathrm{~N}_{\text {fine }}$ at Rishiri $(p=0.06, n=10)$.

At the urban site, Sapporo, monthly weighted-average $\Delta{ }^{17} \mathrm{O}_{\text {wet }}$ ranged between +23.0 and $+30.8 \%$ and was higher than $\Delta \Delta^{17} \mathrm{O}_{\mathrm{dry}}$, which ranged between +18.8 and $+25.0 \%$ \% $(p<0.001, n=12$; Fig. 3$)$. Monthly weightedaverage $\delta^{18} \mathrm{O}_{\text {wet }}$ was higher than $\delta^{18} \mathrm{O}_{\text {dry }}$, with ranges between +70.7 and $+92.2 \%$ and +56.8 and $+70.8 \%$, respectively ( $p<0.0001, n=12$; Fig. 3 ). $\Delta^{17} \mathrm{O}_{\text {dry }}$ and $\delta^{18} \mathrm{O}_{\text {dry }}$ at Sapporo displayed less pronounced seasonal variation than $\Delta \Delta^{17} \mathrm{O}_{\text {wet }}$ and $\delta^{18} \mathrm{O}_{\text {wet }}$ (Figs. 3 and 4). $\Delta^{17} \mathrm{O}_{\text {coarse was more }}$ positive (by $3.9 \%$, on average) than $\Delta^{17} \mathrm{O}_{\text {fine }}(p<0.001$,

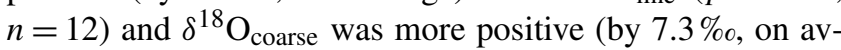
erage) than $\delta^{18} \mathrm{O}_{\text {fine }}(p=0.004, n=12$, respectively) at Sapporo (Fig. S1 in the Supplement). Monthly weighted-average $\delta^{15} \mathrm{~N}_{\mathrm{dry}}$ at Sapporo varied between +0.5 and $+11.2 \%$ o 

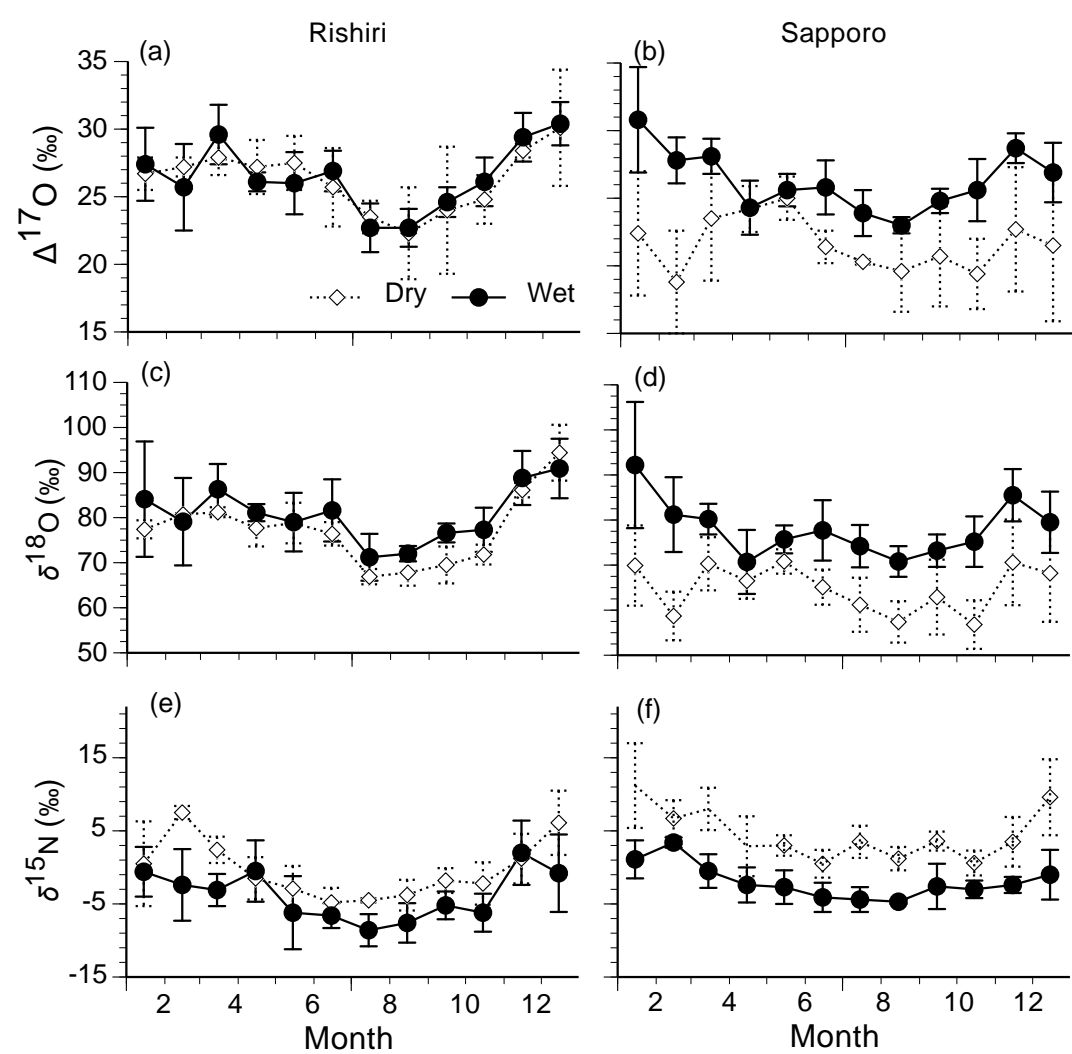

Figure 3. Time series of monthly weighted-average (a, b) $\Delta^{17} \mathrm{O}$ values of nitrate in dry and wet deposition, $(\mathbf{c}, \mathbf{d}) \delta^{18} \mathrm{O}$ values of nitrate in dry and wet deposition, and (e, f) $\delta^{15} \mathrm{~N}$ values of nitrate in dry and wet deposition. Data from Rishiri (rural) are in left column and data from Sapporo (urban) are in right column. Error bars on isotopic values of nitrate in dry deposition represent one standard deviation of isotopic values of nitrate in coarse and fine particles and in gaseous form, whereas errors bars on isotopic values of nitrate in wet deposition represent one standard deviation of all isotopic values of nitrate in wet deposition made during the sampling period.

and was on average $6.5 \%$ larger than $\delta^{15} \mathrm{~N}_{\text {wet }}$, which varied between -4.7 and $+3.4 \%$ o $(p<0.001, n=12$; Fig. 3$)$. $\delta^{15} \mathrm{~N}_{\text {coarse }}$ was on average $3.4 \%$ less than $\delta^{15} \mathrm{~N}_{\text {fine }}$ at Sapporo $(p=0.04, n=12)$.

$\Delta{ }^{17} \mathrm{O}_{\text {wet }}$ at Sapporo exhibited similar values and seasonal patterns as $\Delta^{17} \mathrm{O}_{\text {dry }}$ and $\Delta^{17} \mathrm{O}_{\text {wet }}$ at Rishiri $(p=0.97$, $n=12)$. The difference between $\delta^{15} \mathrm{~N}_{\text {dry }}$ and $\delta^{15} \mathrm{~N}_{\text {wet }}$ was greater at Sapporo than Rishiri, and thus $\delta^{15} \mathrm{~N}_{\text {dry }}$ was greater at Sapporo than Rishiri despite $\delta^{15} \mathrm{~N}_{\text {wet }}$ at Sapporo having similar values and seasonal patterns as $\delta^{15} \mathrm{~N}_{\text {wet }}(p=0.36$, $n=12)$ and $\delta^{15} \mathrm{~N}_{\text {dry }}(p=0.46, n=12)$ at Rishiri (Figs. 3 and 4). There were positive correlations between the $\delta^{15} \mathrm{~N}$ and $\Delta{ }^{17} \mathrm{O}$ values of wet and dry deposition at both sites, with the exception of dry deposition at Sapporo (Fig. 5). Fluxes of nitrate in dry particulate deposition and gaseous dry deposition were generally greater at Sapporo than Rishiri (Fig. S1 in the Supplement) because the dry deposition velocity dominates the flux value of dry deposition and it is greater for Rishiri (assumed to be forest) than Sapporo (assumed to be urban).

\section{Discussion}

The similar values and seasonal trends of $\Delta^{17} \mathrm{O}_{\text {dry }}$ and $\Delta{ }^{17} \mathrm{O}_{\text {wet }}$ at Rishiri imply that both forms of deposition experienced similar seasonal variation in photochemical reactions during their production from $\mathrm{NO}_{x}$. The values and trends are consistent with prior empirical studies of $\Delta^{17} \mathrm{O}_{\text {wet }}$ at Rishiri between 2006 and 2007 (Tsunogai et al., 2010) and elsewhere in Japan (Tsunogai et al., 2016). These results also coincide well with model predictions (Alexander et al., 2009), which suggest that they indicate seasonal variation in the relative importance of oxidation of $\mathrm{NO}_{2}$ by $\mathrm{O}_{3}$ vs. $\mathrm{OH}$ in background, free tropospheric air. During summer when solar radiation is high, the relative importance of oxidation of $\mathrm{NO}_{2}$ by $\mathrm{OH}$ is likely greatest, thus decreasing nitrate $\Delta^{17} \mathrm{O}$ values. In contrast, solar radiation is low in winter, which likely causes pathways involving oxidation of $\mathrm{NO}_{2}$ by $\mathrm{O}_{3}$ to be relatively more important, thus increasing nitrate $\Delta^{17} \mathrm{O}$ values. Values of $\Delta \Delta^{17} \mathrm{O}_{\text {wet }}$ at Sapporo were indistinct from those of $\Delta^{17} \mathrm{O}_{\text {dry }}$ and $\Delta^{17} \mathrm{O}_{\text {wet }}$ at Rishiri, and the most straightforward interpretation of these results is that wet deposition 

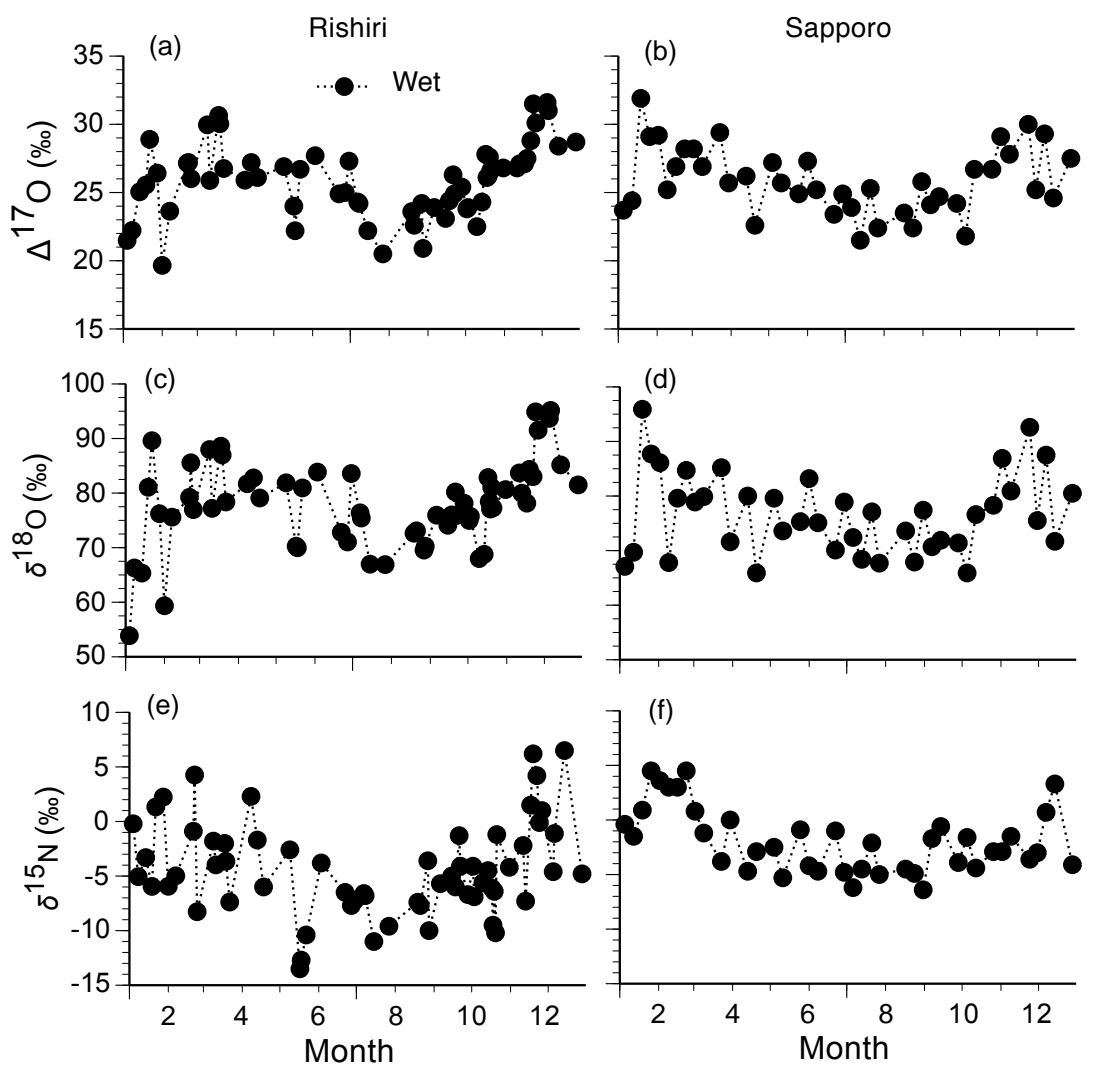

Figure 4. Time series of $(\mathbf{a}, \mathbf{b}) \Delta^{17} \mathrm{O}$ values of nitrate in wet deposition, $(\mathbf{c}, \mathbf{d}) \delta^{18} \mathrm{O}$ values of nitrate in wet deposition, and $(\mathbf{e}, \mathbf{f}) \delta^{15} \mathrm{~N}$ values of nitrate in wet deposition. Data from Rishiri (rural) are in left column and data from Sapporo (urban) are in right column.

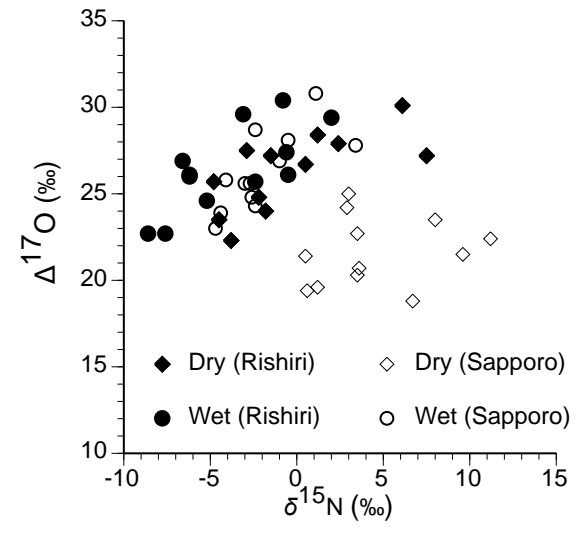

Figure 5. Correlations of $\delta^{15} \mathrm{~N}$ and $\Delta^{17} \mathrm{O}$ values of nitrate in wet and dry deposition at Rishiri and Sapporo. Dry deposition at Rishiri: slope $=0.57$ (95\% confidence interval $=0.15-0.79$ ), $r=0.70, p=0.01, n=12$; wet deposition at Rishiri: slope $=$ $0.74(95 \%$ confidence interval $=0.43-0.97), r=0.73, p=0.007$, $n=12$; dry deposition at Sapporo: $r=0.17, p=0.59, n=12$; wet deposition at Sapporo: slope $=0.95$ (95\% confidence inter$\mathrm{val}=0.33-1.35), r=0.73, p=0.007, n=12$. at Sapporo underwent similar photochemical formation processes as both forms of deposition at Rishiri.

In contrast to $\Delta^{17} \mathrm{O}_{\text {dry }}$ and $\Delta \Delta^{17} \mathrm{O}_{\text {wet }}$ at Rishiri and $\Delta{ }^{17} \mathrm{O}_{\text {wet }}$ at Sapporo, values of $\Delta^{17} \mathrm{O}_{\text {dry }}$ at Sapporo were lower and displayed less seasonal variation. These results suggest unique oxidation processes that display little seasonal variation and are associated with dry deposition at this site. One potential explanation for the relatively low $\Delta{ }^{17} \mathrm{O}_{\text {dry }}$ values at Sapporo relates to $\mathrm{OH}$. Concentrations of $\mathrm{OH}$ are typically higher in urban than rural areas as the result of the formation of $\mathrm{OH}$ from Criegee intermediates during alkene oxidation and/or photolysis of nitrous acid or formaldehyde in more polluted urban settings (Monks, 2005). OH competes with $\mathrm{O}_{3}$ to oxidize $\mathrm{NO}_{2}$, and thus greater oxidation of $\mathrm{NO}_{2}$ by $\mathrm{OH}$ in dry deposition would drive down $\Delta^{17} \mathrm{O}_{\text {dry }}$ values (Morin et al., 2011). Another potential explanation for the relatively low $\Delta^{17} \mathrm{O}_{\text {dry }}$ at Sapporo relates to peroxy radicals potentially being of greater importance in the oxidation of $\mathrm{NO}$ to $\mathrm{NO}_{2}$ in dry deposition at this site. Peroxy radicals typically form via photochemical oxidation of nonmethane hydrocarbons that originate from anthropogenic sources, such as vehicle exhaust, and their concentrations are usually higher in urban than rural environments (Saito et al., 2002; Carslaw et al., 2002). These radicals rapidly compete 
with $\mathrm{O}_{3}$ to oxidize $\mathrm{NO}$ to $\mathrm{NO}_{2}$ (Monks, 2005), which would result in lower $\Delta^{17} \mathrm{O}_{\text {dry }}$ values (Morin et al., 2011). A recent study also suggested that the formation of $\mathrm{NO}_{2}$ by reaction of peroxy radicals with $\mathrm{NO}$ in polluted air caused short-term shifts toward lower $\Delta^{17} \mathrm{O}_{\text {dry }}$ in Taiwan (Guha et al., 2017). Atmospheric inversions are common in Sapporo (Uno et al., 1988) and other Japanese cities (Saito et al., 2002; Uno et al., 1996), particularly during winter, and such conditions may trap pollutants and alter the $\mathrm{NO}_{x}$ to nitrate photo-oxidation pathway thereby helping facilitate reaction of $\mathrm{OH}$ with $\mathrm{NO}_{2}$ and/or NO with peroxy radicals.

Regardless of the precise mechanism driving down $\Delta{ }^{17} \mathrm{O}_{\text {dry }}$ at Sapporo, such low values suggest two distinct sources of nitrate in wet and dry deposition in our study region. The first is likely transported relatively long distances to both Rishiri and Sapporo in wet deposition and to Rishiri in dry deposition. Below-cloud scavenging of local/regional particulate nitrate and gaseous $\mathrm{HNO}_{3}$ undoubtedly occurs at the beginning of precipitation events, but the similar absolute values and temporal variations of $\Delta^{17} \mathrm{O}_{\text {wet }}$ at both sites suggest that the majority of nitrate in wet deposition at Sapporo (as well as Rishiri) originates from afar and is transported to Japan in cloud water. The second source is likely local anthropogenic $\mathrm{NO}_{x}$ emissions that are deposited in dry deposition near their point of production at the urban site, Sapporo, as concentrations of $\mathrm{OH}$ and peroxy radicals are typically elevated in more polluted urban environments (Monks, 2005). Similarly, the more positive values of $\Delta^{17} \mathrm{O}_{\text {coarse }}$ than $\Delta^{17} \mathrm{O}_{\text {fine }}$ at both sites suggest that nitrate in coarse particles is subject to greater supply through long-range transport (produced in free troposphere) than is nitrate in fine particles, which are more influenced by local sources (produced within the boundary layer of the urban area).

To aid our interpretations based on $\Delta^{17} \mathrm{O}$ we evaluated $\delta^{15} \mathrm{~N}$ values of nitrate, which we interpret as primarily indicating variation in $\mathrm{NO}_{x}$ oxidation efficiency (e.g., Walters and Michalski, 2015, 2016; Walters et al., 2016). We recognize that nitrate $\delta^{15} \mathrm{~N}$ values are influenced by factors that are difficult to constrain in our study, including the $\delta^{15} \mathrm{~N}$ values of $\mathrm{NO}_{x}$ from the East Asian continent, the removal rate of $\mathrm{NO}_{x}$ (or production rate of nitrate) during transport, isotopic fractionation between $\mathrm{NO}_{x}$ and nitrate during in-cloud and below-cloud scavenging processes during transport, the $\delta^{15} \mathrm{~N}$ values of locally produced $\mathrm{NO}_{x}$, and the relative amount of $\mathrm{NO}_{x}$ derived locally vs. that from the East Asian continent. Nevertheless, the last factor likely differs the most between our sites since there is more locally produced $\mathrm{NO}_{x}$ in the urban environment at Sapporo. During long-distance transport of $\mathrm{NO}_{x}$ there is greater ${ }^{15} \mathrm{~N}$-enrichment in $\mathrm{NO}_{2}$ than NO (Freyer, 1991), which causes the residual $\mathrm{NO}_{x}$ to become depleted in ${ }^{15} \mathrm{~N}$ during partial removal of $\mathrm{NO}_{x}$ as nitrate in the troposphere. Therefore, nitrate derived from longdistance transport from the East Asian continent is likely to have lower $\delta^{15} \mathrm{~N}$ values than nitrate from more local sources. The relatively high $\delta^{15} \mathrm{~N}_{\text {dry }}$ values at Sapporo are consistent with this interpretation and with the $\Delta^{17} \mathrm{O}$-based inference that nitrate in dry deposition at Sapporo originates from more local sources than does that in wet deposition at Sapporo and both forms of deposition at Rishiri.

The correlations between $\Delta^{17} \mathrm{O}$ and $\delta^{15} \mathrm{~N}$ for both forms of deposition at both sites, with the exception of dry deposition at Sapporo, suggest a relationship between oxidation pathways (recorded by $\Delta^{17} \mathrm{O}$ ) and $\mathrm{NO}_{x}$ oxidation efficiency (recorded by $\delta^{15} \mathrm{~N}$ ). Both $\mathrm{NO}_{x}$ oxidation pathways and efficiencies are primarily controlled by the rate of the $\mathrm{NO}_{2}+\mathrm{OH}$ reaction, which suggests that this reaction drives these correlations. The lack of correlation between $\Delta{ }^{17} \mathrm{O}_{\text {dry }}$ and $\delta^{15} \mathrm{~N}_{\text {dry }}$ at Sapporo likely reflects the unique oxidation pathways (and thus $\Delta^{17} \mathrm{O}$ values) associated with locally produced $\mathrm{NO}_{x}$ in the urban environment.

At both sites, wet and dry deposition exhibited generally larger $\delta^{15} \mathrm{~N}$ values in the winter than summer months. This result probably occurs because of seasonal changes in temperature on isotopic fractionation of nitrogen isotopes and/or in the proportion of $\mathrm{NO}_{2}$ in $\mathrm{NO}_{x}$ (Walters et al., 2016). Overall, our $\delta^{15} \mathrm{~N}$ data suggest that nitrate undergoing longdistance transport and/or production during the summer is likely to have experienced higher $\mathrm{NO}_{x}$ oxidation efficiency than that produced locally and/or during the winter. $\delta^{15} \mathrm{~N}$ values of nitrate likely only reflect those of the source $\mathrm{NO}_{x}$ for nitrate produced locally during the winter. Indeed, the relatively high $\delta^{15} \mathrm{~N}_{\text {dry }}$ values during the winter at Sapporo are consistent with those expected for sources such as nearby combustion of fossil fuels (Redling et al., 2013; Walters et al., 2015).

Overall, our results imply that local-scale efforts to reduce nitrate deposition resulting from local $\mathrm{NO}_{x}$ emissions will be most effective to the extent that dry deposition is the dominant form of atmospheric deposition. Local efforts may be less effective in places and times where atmospheric deposition arrives as wet deposition, since wet deposition seems more likely to originate from long distances. Thus, regional, national and global efforts will likely be required to reduce the effects of atmospheric nitrate in wet deposition which is transported long distances in air masses. Additional datasets with paired measurements of $\Delta{ }^{17} \mathrm{O}_{\text {wet }}$ and $\Delta^{17} \mathrm{O}_{\text {dry }}$ would be valuable to evaluate our interpretation of the oxidation pathways and sources and transport distances of nitrate deposited in urban environments.

The $\Delta^{17} \mathrm{O}$ values of nitrate are increasingly used in watershed studies to determine the relative abundance of unprocessed atmospheric nitrate in environmental waters, such as rivers and lakes (Sabo et al., 2016; Riha et al., 2015; Tsunogai et al., 2010, 2016; Michalski et al., 2004). Such studies often use $\Delta^{17} \mathrm{O}_{\text {wet }}$ or $\Delta^{17} \mathrm{O}_{\text {dry }}$ as an endmember for calculating the amount of unprocessed atmospheric nitrate in a sample. Although they should be validated at other sites, our results suggest that it may be reasonable to assume that $\Delta{ }^{17} \mathrm{O}_{\text {wet }}$ and $\Delta \Delta^{17} \mathrm{O}_{\text {dry }}$ are similar in rural settings, since the annual weighted-average $\Delta^{17} \mathrm{O}$ 
values of wet and dry were nearly identical $(+27.2$ and $+27.1 \%$, respectively) at Rishiri. However, in urban settings or settings downstream of urban environments the potential differences between $\Delta{ }^{17} \mathrm{O}_{\text {wet }}$ and $\Delta{ }^{17} \mathrm{O}_{\text {dry }}$ may need to be considered to avoid over- or under-estimating the amount of unprocessed atmospheric nitrate when using $\Delta^{17} \mathrm{O}$ values of nitrate as a tracer of atmospheric nitrate. For example, consider a simple mixing model such as percent atmospheric nitrate $=100 \times\left[\left(\Delta^{17} \mathrm{O}_{\text {measured }}-\right.\right.$ $\left.\left.\Delta^{17} \mathrm{O}_{\text {terrestrial }}\right) /\left(\Delta^{17} \mathrm{O}_{\text {atmospheric }}-\Delta^{17} \mathrm{O}_{\text {terrestrial }}\right)\right]$, where $\Delta{ }^{17} \mathrm{O}_{\text {measured }}$ is the $\Delta^{17} \mathrm{O}$ value of nitrate in a stream sample, $\Delta \Delta^{17} \mathrm{O}_{\text {terrestrial is }}$ the $\Delta^{17} \mathrm{O}$ value of nitrate containing no atmospheric nitrate (i.e., $0 \%$ ), and $\Delta \Delta^{17} \mathrm{O}_{\text {atmospheric }}$ is the $\Delta^{17} \mathrm{O}$ value of atmospheric nitrate (either +27.6 or $+21.8 \%$, representing the average weighted-average annual values of $\Delta^{17} \mathrm{O}_{\text {wet }}$ and $\Delta{ }^{17} \mathrm{O}_{\text {dry }}$ measured at Sapporo in the present study). The difference in percent atmospheric nitrate when +27.6 and $+21.8 \%$ are used as end-members for $\Delta^{17} \mathrm{O}_{\text {atmospheric }}$ is small when $\Delta^{17} \mathrm{O}_{\text {measured }}$ is small (e.g., $\sim 1 \%$ when $\Delta^{17} \mathrm{O}_{\text {measured }}$ is $\sim 1 \%$ ), but increases when $\Delta{ }^{17} \mathrm{O}_{\text {measured }}$ is large (e.g., $\sim 19 \%$ when $\Delta \Delta^{17} \mathrm{O}_{\text {measured }}$ is $20 \%$ ). Thus, our results suggest a weighted average of $\Delta{ }^{17} \mathrm{O}_{\text {wet }}$ and $\Delta{ }^{17} \mathrm{O}_{\text {dry }}$ should be used when $\Delta{ }^{17} \mathrm{O}$ values of nitrate are used to quantify the amount of unprocessed atmospheric nitrate exported from urban watersheds. At Sapporo, the weighted average of $\Delta^{17} \mathrm{O}_{\text {wet }}$ and $\Delta^{17} \mathrm{O}_{\text {dry }}$ is $+25.7 \%$, which is more similar to $\Delta^{17} \mathrm{O}_{\text {wet }}$ than $\Delta^{17} \mathrm{O}_{\text {dry }}$ at this site since wet deposition comprised the majority of the total deposition at this location. However, $\Delta{ }^{17} \mathrm{O}_{\text {wet }}$ may not as closely approximate the weighted average of $\Delta^{17} \mathrm{O}_{\text {wet }}$ and $\Delta^{17} \mathrm{O}_{\text {dry }}$ at some sites, such as semi-closed and/or highly polluted urban areas, where the majority of deposition comes from local sources.

\section{Conclusions}

Our isotopic data suggest differences in the oxidation chemistry and transport distances of wet and dry deposition in urban settings: wet deposition tends to originate from afar, whereas dry deposition is produced largely from local sources as the result of unique $\mathrm{NO}_{x}$ oxidation pathways that occur in polluted urban settings. These results imply that reductions in local $\mathrm{NO}_{x}$ emissions will be most effective when and where dry deposition is the dominant form of atmospheric deposition, which has implications for efforts to reduce nitrate deposition and its negative environmental impacts in cities and downwind areas. The approach used herein of comparing isotopic values of wet and dry deposition in different environmental settings is likely to provide continued insight into the transport distances and reaction pathways of atmospheric nitrate pollution.
Data availability. All data are available upon request from the corresponding author.

\section{The Supplement related to this article is available online at https://doi.org/10.5194/acp-18-6381-2018-supplement.}

Author contributions. UT, TO, and FN designed the study. UT, TO, DD, FN, IN, DDK, and TY carried out the research. DMN and DD performed data analysis. DMN and TO wrote the manuscript with contributions from all authors. All authors have given approval to the final version of the manuscript.

Competing interests. The authors declare that they have no conflict of interest.

Acknowledgements. We thank the Ministry of the Environment, Japan, for providing the monitoring data from the acid deposition survey and Joel Bostic and the reviewers for providing feedback on an earlier version of the manuscript. This work was supported by a Grant-in-Aid for Scientific Research from the Ministry of Education, Culture, Sports, Science, and Technology of Japan under grants 26241006 and 17H00780 (to UT and FN), 15H02804, and $15 \mathrm{~K} 12187$ (to FN), as well as a visiting research fellowship from Nagoya University and short-term invitation fellowship (grant S17093) from the Japan Society for Promotion of Science (to $\mathrm{DMN})$.

Edited by: Leiming Zhang

Reviewed by: three anonymous referees

\section{References}

Aikawa, M., Ohara, T., Hiraki, T., Oishi, O., Tsuji, A., Yamagami, M., Murano, K., and Mukai, H.: Significant geographic gradients in particulate sulfate over Japan determined from multiple-site measurements and a chemical transport model: Impacts of transboundary pollution from the Asian continent, Atmos. Environ., 44, 381-391, https://doi.org/10.1016/j.atmosenv.2009.10.025, 2010 .

Akimoto, H.: Global air quality and pollution, Science, 302, 17161719, https://doi.org/10.1126/science.1092666, 2003.

Alexander, B., Hastings, M. G., Allman, D. J., Dachs, J., Thornton, J. A., and Kunasek, S. A.: Quantifying atmospheric nitrate formation pathways based on a global model of the oxygen isotopic composition $\left(\Delta^{17} \mathrm{O}\right)$ of atmospheric nitrate, Atmos. Chem. Phys., 9, 5043-5056, https://doi.org/10.5194/acp-9-5043-2009, 2009.

Balestrini, R., Galli, L., and Tartari, G.: Wet and dry atmospheric deposition at prealpine and alpine sites in northern Italy, Atmos. Environ., 34, 1455-1470, https://doi.org/10.1016/S13522310(99)00404-5, 2000. 
Ban, S., Matsuda, K., Sato, K., and Ohizumi, T.: Longterm assessment of nitrogen deposition at remote EANET sites in Japan, Atmos. Environ., 146, 70-78, https://doi.org/10.1016/j.atmosenv.2016.04.015, 2016.

Bloom, D. E., Canning, D., and Fink, G.: Urbanization and the wealth of nations, Science, 319, 772-775, https://doi.org/10.1126/science.1153057, 2008.

Brown, S. S., Ryerson, T. B., Wollny, A. G., Brock, C. A., Peltier, R., Sullivan, A. P., Weber, R. J., Dube, W. P., Trainer, M., Meagher, J. F., Fehsenfeld, F. C., and Ravishankara, A. R.: Variability in nocturnal nitrogen oxide processing and its role in regional air quality, Science, 311, 67-70, https://doi.org/10.1126/science.1120120, 2006.

Carslaw, N., Creasey, D. J., Heard, D. E., Jacobs, P. J., Lee, J. D., Lewis, A. C., McQuaid, J. B., Pilling, M. J., Bauguitte, S., Penkett, S. A., Monks, P. S., and Salisbury, G.: Eastern Atlantic Spring Experiment 1997 (EASE97) - 2. Comparisons of model concentrations of $\mathrm{OH}, \mathrm{HO}_{2}$, and $\mathrm{RO}_{2}$ with measurements, J. Geophys. Res.-Atmos., 107, 4190, https://doi.org/10.1029/2001jd001568, 2002.

Casciotti, K. L., Bohlke, J. K., McIlvin, M. R., Mroczkowski, S. J., and Hannon, J. E.: Oxygen isotopes in nitrite: Analysis, calibration, and equilibration, Anal. Chem., 79, 2427-2436, https://doi.org/10.1021/ac061598h, 2007.

Celle-Jeanton, H., Travi, Y., Loye-Pilot, M. D., Huneau, F., and Bertrand, G.: Rainwater chemistry at a Mediterranean inland station (Avignon, France): Local contribution versus long-range supply, Atmos. Res., 91, 118-126, https://doi.org/10.1016/j.atmosres.2008.06.003, 2009.

Crutzen, P. J.: Role of $\mathrm{NO}$ and $\mathrm{NO}_{2}$ in the chemistry of the troposphere and stratosphere, Annu. Rev. Earth Pl. Sc., 7, 443-472, https://doi.org/10.1146/annurev.ea.07.050179.002303, 1979.

Cumming, G. S., Buerkert, A., Hoffmann, E. M., Schlecht, E., von Cramon-Taubadel, S., and Tscharntke, T.: Implications of agricultural transitions and urbanization for ecosystem services, Nature, 515, 50-57, https://doi.org/10.1038/nature13945, 2014.

Dasch, J. M. and Cadle, S. H.: Wet and dry deposition monitoring in southeastern Michigan, Atmos. Environ., 19, 789-796, https://doi.org/10.1016/0004-6981(85)90067-8, 1985.

Elliott, E. M., Kendall, C., Boyer, E. W., Burns, D. A., Lear, G. G., Golden, H. E., Harlin, K., Bytnerowicz, A., Butler, T. J., and Glatz, R.: Dual nitrate isotopes in dry deposition: Utility for partitioning $\mathrm{NO}_{x}$ source contributions to landscape nitrogen deposition, J. Geophys. Res.-Biogeol., 114, G04020, https://doi.org/10.1029/2008JG000889, 2009.

Endo, T., Yagoh, H., Sato, K., Matsuda, K., Hayashi, K., Noguchi, I., and Sawada, K.: Regional characteristics of dry deposition of sulfur and nitrogen compounds at EANET sites in Japan from 2003 to 2008, Atmos. Environ., 45, 1259-1267, https://doi.org/10.1016/j.atmosenv.2010.12.003, 2011.

Erisman, J. W., Draaijers, G., Duyzer, J., Hofschreuder, P., VanLeeuwen, N., Romer, F., Ruijgrok, W., Wyers, P., and Gallagher, M.: Particle deposition to forests - Summary of results and application, Atmos. Environ., 31, 321-332, https://doi.org/10.1016/S1352-2310(96)00223-3, 1997.

Fang, Y. T., Koba, K., Wang, X. M., Wen, D. Z., Li, J., Takebayashi, Y., Liu, X. Y., and Yoh, M.: Anthropogenic imprints on nitrogen and oxygen isotopic composition of precipitation nitrate in a nitrogen-polluted city in southern China, Atmos.
Chem. Phys., 11, 1313-1325, https://doi.org/10.5194/acp-111313-2011, 2011.

Fraser, M. P., Cass, G. R., and Simoneit, B. R. T.: Gas-phase and particle-phase organic compounds emitted from motor vehicle traffic in a Los Angeles roadway tunnel, Environ. Sci. Technol. 32, 2051-2060, https://doi.org/10.1021/es970916e, 1998.

Freyer, H. D.: Seasonal variation of ${ }^{15} \mathrm{~N} /{ }^{14} \mathrm{~N}$ ratios in atmospheric nitrate species, Tellus B, 43, 30-44, https://doi.org/10.1034/j.1600-0889.1991.00003.x, 1991.

Freyer, H. D., Kley, D., Volzthomas, A., and Kobel, K.: On the interaction of isotopic exchange processes with photochemical reactions in atmospheric oxides of nitrogen, J. Geophys. Res.Atmos., 98, 14791-14796, https://doi.org/10.1029/93jd00874, 1993.

Galloway, J. N., Dentener, F. J., Capone, D. G., Boyer, E. W., Howarth, R. W., Seitzinger, S. P., Asner, G. P., Cleveland, C. C., Green, P. A., Holland, E. A., Karl, D. M., Michaels, A. F., Porter, J. H., Townsend, A. R., and Vorosmarty, C. J.: Nitrogen cycles: past, present, and future, Biogeochemistry, 70, 153-226, 2004.

Geng, L., Murray, L. T., Mickley, L. J., Lin, P., Fu, Q., Schauer, A. J., and Alexander, B.: Isotopic evidence of multiple controls on atmospheric oxidants over climate transitions, Nature, 546, 133136, https://doi.org/10.1038/nature22340, 2017.

Guerrieri, R., Vanguelova, E. I., Michalski, G., Heaton, T. H. E., and Mencuccini, M.: Isotopic evidence for the occurrence of biological nitrification and nitrogen deposition processing in forest canopies, Glob. Change Biol., 21, 4613-4626, https://doi.org/10.1111/gcb.13018, 2015.

Guha, T., Lin, C. T., Bhattacharya, S. K., Mahajan, A. S., Ou-Yang, C.-F., Lan, Y.-P., Hsu, S. C., and Liang, M.-C.: Isotopic ratios of nitrate in aerosol samples from Mt. Lulin, a high-altitude station in Central Taiwan, Atmos. Environ., 154, 53-69, 2017.

Gurjar, B. R., Ravindra, K., and Nagpure, A. S.: Air pollution trends over Indian megacities and their localto-global implications, Atmos. Environ., 142, 475-495, https://doi.org/10.1016/j.atmosenv.2016.06.030, 2016.

Hammer, Ø., Harper, D. A. T., and Ryan, P. D.: PAST: Paleontological statistics software package for education and data analysis, Palaeontol. Electron., 4, 9 pp., 2001.

Hicks, B. B.: Measuring dry deposition: A reassessment of the state-of-the-art, Water Air Soil Poll., 30, 75-90, https://doi.org/10.1007/Bf00305177, 1986.

Hirota, A., Tsunogai, U., Komatsu, D. D., and Nakagawa, F.: Simultaneous determination of $\delta^{15} \mathrm{~N}$ and $\delta^{18} \mathrm{O}$ of $\mathrm{N}_{2} \mathrm{O}$ and $\delta^{13} \mathrm{C}$ of $\mathrm{CH}_{4}$ in nanomolar quantities from a single water sample, Rapid Commun. Mass Sp., 24, 1085-1092, https://doi.org/10.1002/rcm.4483, 2010.

Holtgrieve, G. W., Schindler, D. E., Hobbs, W. O., Leavitt, P. R., Ward, E. J., Bunting, L., Chen, G. J., Finney, B. P., GregoryEaves, I., Holmgren, S., Lisac, M. J., Lisi, P. J., Nydick, K., Rogers, L. A., Saros, J. E., Selbie, D. T., Shapley, M. D., Walsh, P. B., and Wolfe, A. P.: A coherent signature of anthropogenic nitrogen deposition to remote watersheds of the Northern hemisphere, Science, 334, 1545-1548, 2011.

Kaiser, J., Hastings, M. G., Houlton, B. Z., Rockmann, T., and Sigman, D. M.: Triple oxygen isotope analysis of nitrate using the denitrifier method and thermal decomposition of $\mathrm{N}_{2} \mathrm{O}$, Anal. Chem., 79, 599-607, 2007. 
Kaneyasu, N., Ohta, S., and Murao, N.: Seasonal variation in the chemical composition of atmospheric aerosols and gaseous species in Sapporo, Japan, Atmos. Environ., 29, 1559-1568, https://doi.org/10.1016/1352-2310(94)00356-P, 1995.

Kendall, C., Elliott, E. M., and Wankel, S. D.: Tracing anthropogenic input of nitrogen to ecosytems, in: Stable Isotopes in Ecology and Environmental Science, edited by: Michener, R. H., and Lajtha, L. J., Blackwell, Oxford, 375-449, 2007.

Komatsu, D. D., Ishimura, T., Nakagawa, F., and Tsunogai, U.: Determination of the ${ }^{15} \mathrm{~N} /{ }^{14} \mathrm{~N},{ }^{17} \mathrm{O} /{ }^{16} \mathrm{O}$, and ${ }^{18} \mathrm{O} /{ }^{16} \mathrm{O}$ ratios of nitrous oxide by using continuous-flow isotope-ratio mass spectrometry, Rapid Commun. Mass Sp., 22, 1587-1596, 2008.

Li, Y., Schichtel, B. A., Walker, J. T., Schwede, D. B., Chen, X., Lehmann, C. M. B., Puchalski, M. A., Gay, D. A., and Collett, J. L.: Increasing importance of deposition of reduced nitrogen in the United States, P. Natl. Acad. Sci. USA, 113, 5874-5879, https://doi.org/10.1073/pnas.1525736113, 2016.

Lin, M. Y., Horowitz, L. W., Payton, R., Fiore, A. M., and Tonnesen, G.: US surface ozone trends and extremes from 1980 to 2014: Quantifying the roles of rising Asian emissions, domestic controls, wildfires, and climate, Atmos. Chem. Phys., 17, 29432970, https://doi.org/10.5194/acp-17-2943-2017, 2017.

Liu, F., Zhang, Q., Ronald, J. V., Zheng, B., Tong, D., Yan, L., Zheng, Y. X., and He, K. B.: Recent reduction in $\mathrm{NO}_{x}$ emissions over China: synthesis of satellite observations and emission inventories, Environ. Res. Lett., 11, 114002, https://doi.org/10.1088/1748-9326/11/11/114002, 2016.

McIlvin, M. R. and Altabet, M. A.: Chemical conversion of nitrate and nitrite to nitrous oxide for nitrogen and oxygen isotopic analysis in freshwater and seawater, Anal. Chem., 77, 5589-5595, https://doi.org/10.1021/ac050528s, 2005.

Mehlmann, A. and Warneck, P.: Atmospheric gaseous $\mathrm{HNO}_{3}$ particulate nitrate, and aerosol-size distributions of major ionic species at a rural site in western Germany, Atmos. Environ., 29, 23592373, https://doi.org/10.1016/1352-2310(95)00056-5, 1995.

Michalski, G., Scott, Z., Kabiling, M., and Thiemens, M. H.: First measurements and modeling of $\Delta^{17} \mathrm{O}$ in atmospheric nitrate, Geophys. Res. Lett., 30, 1870, https://doi.org/10.1029/2003GL017015, 2003.

Michalski, G., Meixner, T., Fenn, M., Hernandez, L., Sirulnik, A., Allen, E., and Thiemens, M.: Tracing atmospheric nitrate deposition in a complex semiarid ecosystem using $\Delta^{17} \mathrm{O}$, Environ. Sci. Technol., 38, 2175-2181, 2004.

Michalski, G., Bhattacharya, S. K., and Mase, D. F.: Oxygen Isotope Dynamics of Atmospheric Nitrate and Its Precursor Molecules, in: Handbook of Environmental Isotope Geochemistry, Advances in Isotope Geochemistry, edited by: Baskaran, M., Springer Verlag, Berlin, 613-635, 2011.

Monks, P. S.: Gas-phase radical chemistry in the troposphere, Chem. Soc. Rev., 34, 376-395, https://doi.org/10.1039/b307982c, 2005.

Morin, S., Savarino, J., Frey, M. M., Yan, N., Bekki, S., Bottenheim, J. W., and Martins, J. M. F.: Tracing the origin and fate of $\mathrm{NO}_{x}$ in the Arctic atmosphere using stable isotopes in nitrate, Science, 322, 730-732, https://doi.org/10.1126/science.1161910, 2008.

Morin, S., Sander, R., and Savarino, J.: Simulation of the diurnal variations of the oxygen isotope anomaly $\left(\Delta^{17} \mathrm{O}\right)$ of reactive atmospheric species, Atmos. Chem. Phys., 11, 3653-3671, https://doi.org/10.5194/acp-11-3653-2011, 2011.
Noguchi, I., Aosier, B., Takada, M., Hamahara, K., Takahashi, H., and Tamada, K.: Developing NDVI Estimation Model of Forest Area in Japan, using Temperature data, Report of Institute of Environmental Sciences, 43-56, 2006.

Noguchi, I., Yamaguchi, T., Sakai, S., and Tsunogai, U.: Comparison of air pollutant measurements by weekly, biweekly, and monthly filter-pack method, Proceedings of the 50th Annual meeting of Japan Society for Atmospheric Environment, 16-18 September 2009, Keio University Hiyoshi Campus, Yokohama, Japan 2009.

Noguchi, I., Yamaguchi, T., Kawamura, M., Matsumoto, R., and Matsuda, K.: Updated program file for dry deposition velocity, Report of Institute of Environmental Sciences, 21-31, 2011.

Redling, K., Elliott, E., Bain, D., and Sherwell, J.: Highway contributions to reactive nitrogen deposition: tracing the fate of vehicular $\mathrm{NO}_{x}$ using stable isotopes and plant biomonitors, Biogeochemistry, 116, 261-274, https://doi.org/10.1007/s10533-0139857-x, 2013.

Riha, K. M., Michalski, G., Gallo, E. L., Lohse, K. A., Brooks, P. D., and Meixner, T.: High atmospheric nitrate inputs and nitrogen turnover in semi-arid urban catchments, Ecosystems, 17, 13091325, 2015.

Sabo, R. D., Nelson, D. M., and Eshleman, K. N.: Episodic, seasonal, and annual export of atmospheric and microbial nitrate from a temperate forest, Geophys. Res. Lett., 43, 683-691, https://doi.org/10.1002/2015g1066758, 2016.

Saito, S., Nagao, I., and Tanaka, H.: Relationship of $\mathrm{NO}_{x}$ and NMHC to photochemical $\mathrm{O}_{3}$ production in a coastal and metropolitan areas of Japan, Atmos. Environ., 36, 1277-1286, https://doi.org/10.1016/S1352-2310(01)00557-X, 2002.

Savarino, J., Kaiser, J., Morin, S., Sigman, D. M., and Thiemens, M. H.: Nitrogen and oxygen isotopic constraints on the origin of atmospheric nitrate in coastal Antarctica, Atmos. Chem. Phys., 7, 1925-1945, https://doi.org/10.5194/acp-7-1925-2007, 2007.

Skyllakou, K., Murphy, B. N., Megaritis, A. G., Fountoukis, C., and Pandis, S. N.: Contributions of local and regional sources to fine PM in the megacity of Paris, Atmos. Chem. Phys., 14, 2343 2352, https://doi.org/10.5194/acp-14-2343-2014, 2014.

Sofen, E. D., Alexander, B., Steig, E. J., Thiemens, M. H., Kunasek, S. A., Amos, H. M., Schauer, A. J., Hastings, M. G., Bautista, J., Jackson, T. L., Vogel, L. E., McConnell, J. R., Pasteris, D. R., and Saltzman, E. S.: WAIS Divide ice core suggests sustained changes in the atmospheric formation pathways of sulfate and nitrate since the 19th century in the extratropical Southern Hemisphere, Atmos. Chem. Phys., 14, 5749-5769, https://doi.org/10.5194/acp-14-5749-2014, 2014.

Tørseth, K., Hanssen, J. E., and Semb, A.: Temporal and spatial variations of airborne $\mathrm{Mg}, \mathrm{Cl}, \mathrm{Na}, \mathrm{Ca}$ and $\mathrm{K}$ in rural areas of Norway, Sci. Total Environ., 234, 75-85, https://doi.org/10.1016/S0048-9697(99)00261-2, 1999.

Tsunogai, U., Kido, T., Hirota, A., Ohkubo, S. B., Komatsu, D. D., and Nakagawa, F.: Sensitive determinations of stable nitrogen isotopic composition of organic nitrogen through chemical conversion into $\mathrm{N}_{2} \mathrm{O}$, Rapid Commun. Mass Sp., 22, 345-354, https://doi.org/10.1002/rcm.3368, 2008.

Tsunogai, U., Komatsu, D. D., Daita, S., Kazemi, G. A., Nakagawa, F., Noguchi, I., and Zhang, J.: Tracing the fate of atmospheric nitrate deposited onto a forest ecosystem in East- 
ern Asia using $\Delta^{17} \mathrm{O}$, Atmos. Chem. Phys., 10, 1809-1820, https://doi.org/10.5194/acp-10-1809-2010, 2010.

Tsunogai, U., Miyauchi, T., Ohyama, T., Komatsu, D. D., Nakagawa, F., Obata, Y., Sato, K., and Ohizumi, T.: Accurate and precise quantification of atmospheric nitrate in streams draining land of various uses by using triple oxygen isotopes as tracers, Biogeosciences, 13, 3441-3459, https://doi.org/10.5194/bg-133441-2016, 2016.

United Nations: World Urbanization Prospects, the 2014 Revision, United Nations, Population Division, Department of Economic and Social Affairs, New York, 32 pp., 2014.

Uno, I., Wakamatsu, S., and Ueda, H.: Behavior of nocturnal urban boundary layer and air pollutants, J. Jpn. Soc. Air Poll., 23, 102$114,1988$.

Uno, I., Ohara, T., and Wakamatsu, S.: Analysis of wintertime $\mathrm{NO}_{2}$ pollution in the Tokyo Metropolitan area, Atmos. Environ., 30, 703-713, https://doi.org/10.1016/1352-2310(95)00177-8, 1996.

Uno, I., Uematsu, M., Hara, Y., He, Y. J., Ohara, T., Mori, A., Kamaya, T., Murano, K., Sadanaga, Y., and Bandow, H.: Numerical study of the atmospheric input of anthropogenic total nitrate to the marginal seas in the western North Pacific region, Geophys. Res. Lett., 34, L17817, https://doi.org/10.1029/2007gl030338, 2007.

von Glasow, R., Jickells, T. D., Baklanov, A., Carmichael, G. R., Church, T. M., Gallardo, L., Hughes, C., Kanakidou, M., Liss, P. S., Mee, L., Raine, R., Ramachandran, P., Ramesh, R., Sundseth, K., Tsunogai, U., Uematsu, M., and Zhu, T.: Megacities and large urban agglomerations in the coastal zone: Interactions between atmosphere, land, and marine ecosystems, Ambio, 42, 13-28, https://doi.org/10.1007/s13280-012-0343-9, 2013.

Wagstrom, K. M. and Pandis, S. N.: Contribution of long range transport to local fine particulate matter concerns, Atmos. Environ., 45, 2730-2735, https://doi.org/10.1016/j.atmosenv.2011.02.040, 2011.

Walcek, C. J., Brost, R. A., Chang, J. S., and Wesely, M. L.: $\mathrm{SO}_{2}$, sulfate and $\mathrm{HNO}_{3}$ deposition velocities computed using regional landuse and meteorological data, Atmos. Environ., 20, 949-964, https://doi.org/10.1016/0004-6981(86)90279-9, 1986.
Walters, W. W. and Michalski, G.: Theoretical calculation of nitrogen isotope equilibrium exchange fractionation factors for various $\mathrm{NO}_{y}$ molecules, Geochim. Cosmochim. Ac., 164, 284-297, https://doi.org/10.1016/j.gca.2015.05.029, 2015.

Walters, W. W. and Michalski, G.: Theoretical calculation of oxygen equilibrium isotope fractionation factors involving various $\mathrm{NO}_{y}$ molecules, $\mathrm{OH}$, and $\mathrm{H}_{2} \mathrm{O}$ and its implications for isotope variations in atmospheric nitrate, Geochim. Cosmochim. Ac., 191, 89-101, https://doi.org/10.1016/j.gca.2016.06.039, 2016.

Walters, W. W., Tharp, B. D., Fang, H., Kozak, B. J., and Michalski, G.: Nitrogen isotope composition of thermally produced $\mathrm{NO}_{x}$ from various fossil-fuel combustion sources, Environ. Sci. Technol., 49, 11363-11371, https://doi.org/10.1021/acs.est.5b02769, 2015.

Walters, W. W., Simonini, D. S., and Michalski, G.: Nitrogen isotope exchange between $\mathrm{NO}$ and $\mathrm{NO}_{2}$ and its implications for $\delta^{15} \mathrm{~N}$ variations in tropospheric $\mathrm{NO}_{x}$ and atmospheric nitrate, Geophys. Res. Lett., 43, 440-448, https://doi.org/10.1002/2015gl066438, 2016.

Wesely, M. L.: Parameterization of surface resistances to gaseous dry deposition in regional-scale numerical models, Atmos. Environ., 23, 1293-1304, https://doi.org/10.1016/00046981(89)90153-4, 1989.

Zhang, L., Brook, J. R., and Vet, R.: A revised parameterization for gaseous dry deposition in air-quality models, Atmos. Chem. Phys., 3, 2067-2082, https://doi.org/10.5194/acp-3-2067-2003, 2003.

Zhao, Y., Qiu, L. P., Xu, R. Y., Xie, F. J., Zhang, Q., Yu, Y. Y., Nielsen, C. P., Qin, H. X., Wang, H. K., Wu, X. C., Li, W. Q., and Zhang, J.: Advantages of a city-scale emission inventory for urban air quality research and policy: the case of Nanjing, a typical industrial city in the Yangtze River Delta, China, Atmos. Chem. Phys., 15, 12623-12644, https://doi.org/10.5194/acp-15-12623$2015,2015$. 